\title{
ACHEGAS PARA A HISTÓRIA DO ENSINO SECUNDÁRIO PARTICULAR
} (1949-1974)

\author{
António Manuel Matoso Martinho*
}

\section{EVOLUÇÃO}

Com o advento do Estado Novo (1926) vão processar-se extensas reformas nos diferentes sectores da educação e, entre eles, no do ensino secundário particular.

A publicação, em 1931, do Estatuto do Ensino Particular ${ }^{1}$ veio conferir uma maior dignidade ao ensino particular, identificando-o com o ensino estatal na cooperação manifestada à familia, a quem, fundamentalmente, pertence a educação.

O Estado favorecia as escolas particulares que podiam ser subsidiadas para efeitos de concessão de diplomas. A criação de estabelecimentos de ensino particular $^{2}$ era livre ${ }^{3}$, embora o seu ensino se encontrasse sujeito à inspecção do Estado ${ }^{4}$.

Os planos de estudo e os horários semanais podiam diferir dos do ensino oficial $^{5}$ e, embora o ensino particular se regulasse pelos princípios da moral cristã que também informava o ensino oficial, este era independente de qualquer culto ${ }^{6}$.

\subsection{A Constituição de 1933 e o Ensino Particular}

É, porém, a Constituição Política de 1933 que estabelece a liberdade de ensino ao afirmar que «é livre o estabelecimento de escolas particulares paralelas às do Estado, ficando sujeitas à fiscalização deste e podendo ser por ele subsidiadas ou oficializadas para o efeito de concederem diplomas quando os seus programas e categorias do respectivo pessoal docente não forem inferiores aos dos estabelecimentos oficiais similares» ${ }^{7}$; ao referir que é dever do «Estado facilitar aos pais o cumprimento do dever de instruir e educar os filhos, cooperando com eles por meio de estabelecimentos oficiais de ensino e correcção, ou favorecendo instituições particulares que se destinem ao mesmo fim ${ }^{8} \mathrm{e}$ ao afirmar ser uma liberdade fundamental dos portugueses a liberdade de ensino» ${ }^{9}$.

* Escola Superior de Educação do Instituto Politécnico da Guarda; Faculdade de Letras do Pólo de Viseu da Universidade Católica Portuguesa. 
Desta situação parece decorrer uma concepção de liberdade de ensino inspirada nas exigências do Direito Natural e da doutrina da Igreja ${ }^{10}$ pois, como escreveu António Leite, a liberdade de ensino é a «liberdade para os pais de escolherem, dentro do razoável, as escolas para os seus filhos e a liberdade das pessoas moral e intelectualmente idóneas ou associações para abrirem escolas e ensinarem ${ }^{11}$.

Pertence, assim, aos pais o direito e o dever de escolherem para os seus filhos a educação e os educadores mais consentâneos com os seus desejos. Os direitos dos Pais em matéria de educação constituem, assim, um direito natural. Daí, afirmar-se, que os pais são os primeiros e principais responsáveis pela educação dos seus filhos.

A Declaração Universal dos Direitos do Homem consagra este direito no seu artigo 26 ao afirmar: «a pessoa humana tem direito à educação (...). Os Pais têm por prioridade o direito de escolher o género de educação a dar aos seus filhos» $\mathrm{e}$, na Declaração dos Direitos da Criança, no artigo $7 .^{\circ}$, pode ler-se: «o superior interesse da criança deve ser o primeiro objectivo de quem tem a responsabilidade da sua educação e orientação - esta responsabilidade cabe, em primeiro lugar, a seus pais».

A este direito dos Pais corresponderá a possibilidade efectiva de o poderem exercer em igualdade de oportunidades.

Deste modo, poderemos concluir que o ensino particular se fundamenta no direito dos pais sobre a educação dos seus filhos e na liberdade de ensino.

\subsubsection{O Ensino Particular - diplomas orientadores}

O ensino particular tem vindo a ser regulado pelos seguintes diplomas legislativos:

- Constituição Política (1933);

- Concordata com a Santa Sé (7 de Maio de 1940);

- Decreto n. ${ }^{\circ}$ 36508, de 17 de Setembro de 1947 (Estatuto do Ensino Liceal) $^{12}$;

- Decreto n. ${ }^{\circ} 37029$, de 25 de Agosto de 1948 (Estatuto do Ensino Técnico Profissional $^{13}$;

- Lei n. ${ }^{\circ} 2033$, de 27 de Junho de $1949^{14}$;

- Decreto n. $^{\circ} 37544$, de 8 de Setembro de $1949^{15}$;

- Decreto-Lei n. ${ }^{\circ}$ 37545, de 8 de Setembro de 1949 (Estatuto do Ensino Particular $)^{16}$

- Decreto n. ${ }^{\circ} 41192$, de 18 de Julho de $1957^{17}$.

Ao longo dos anos esta legislação foi sendo esclarecida e, até mesmo, alterada por outros diplomas, especialmente circulares ${ }^{18}$. 


\subsubsection{Princípios fundamentais}

Se na ordem temporal a primeira responsabilidade educativa é da família — os filhos são um prolongamento dos pais -, na ordem natural a família insere-se na sociedade civil que a completa e de que o Estado é a mais legítima expressão social.

Daí o Estado possuir direitos e deveres no domínio educativo.

1. Na Constituição Política (1933):

a) Incumbe ao Estado:

«Promover a unidade e estabelecer a ordem jurídica da Nação, definindo e fazendo respeitar os, direitos e garantias impostos pela moral, pela justiça ou pela lei, em favor dos indivíduos, das famílias, das autarquias locais e das outras pessoas colectivas, públicas ou privadas $(\ldots)^{19}{ }^{19}$.

b) Constituem direitos, liberdades e garantias individuais dos cidadãos portugueses:

$5 .^{\circ}$ A liberdade de ensino ${ }^{20}$.

c) «O Estado assegura a constituição e defesa da família, como fonte de conservação e desenvolvimento do povo português, como base primária da educação, da disciplina e harmonia social e como fundamento da ordem política e administrativa, pela sua agregação e representação na freguesia e no município» ${ }^{21}$.

d) Em ordem à defesa das famílias pertence ao Estado e autarquias locais:

4. «Facilitar aos pais o cumprimento do dever de instruir e educar os filhos, cooperando com eles por meio de estabelecimentos oficiais de ensino e correcção, ou favorecendo instituições particulares que se destinem ao mesmo fim (...) ${ }^{22}$.

e) «A educação e instrução são obrigatórias e pertencem à família e aos estabelecimentos oficiais ou particulares em cooperação com ela» ${ }^{23}$.

f) «É livre o estabelecimento de escolas particulares paralelas às do Estado, ficando sujeitas à físcalização deste e podendo ser por ele subsidiadas, ou oficializadas para o efeito de concederem diplomas quando os seus programas e categoria do respectivo pessoal docente não forem inferiores aos dos estabelecimentos oficiais ${ }^{24}$.

\section{Da Concordata com a Santa Sé (1940):}

«As associações e organizações da Igreja podem livremente estabelecer e manter escolas particulares paralelas às do Estado, ficando sujeitas, nos termos do direito comum, à fiscalização deste e podendo, nos mesmos termos, ser subsidiadas e oficializadas» ${ }^{25}$. 
Porém, o Estatuto do Ensino Particular acabou por ser profundamente restritivo relativamente aos preceitos constitucionais referidos, o que, embora não interferindo directamente na vida interna das escolas, não deixou de conferir ao Governo poderes que lhe permitiam um autêntico controle do ensino.

Assim, «os estabelecimentos de ensino particular enviarão à Inspecção cópias de todos os seus regulamentos internos, de circulares expedidas, de anúncios e de todas as suas publicações, bem como das relações sempre actualizadas do seu pessoal docente, incluindo o médico ou médicos escolares, com menção da remuneração atribuída aos respectivos serviços» ${ }^{26}$.

E, ainda, no mesmo artigo: «quaisquer publicações de autoria de alunos, ou em que estes colaborem, serão sempre orientados ou fiscalizados pela direcção do estabelecimento, que enviará um exemplar à Inspecção» ${ }^{27}$.

No que respeita à constituição do corpo docente das escolas particulares, o Estatuto do Ensino Particular apenas fixa as habilitações mínimas que os professores devem possuir para os diferentes grupos e disciplinas, não interferindo, assim, nas escolas cuja responsabilidade pertence à Direcção das mesmas.

O mesmo já não se pode afirmar em relação aos currículos e programas, uma vez que o Estatuto afirma claramente - sem prejuízo do disposto no n. $^{\circ} 3$ do artigo $2 .{ }^{\circ 28}$ : «os estabelecimentos de ensino particular devem adoptar os planos e programas do ensino oficial, bem como os compêndios nele aprovados, e não podem dedicar às aulas ou sessões menos tempo do que o previsto para aquele ensino» ${ }^{29}$.

Deste modo, quanto a planos de estudo, currículos, programas e manuais escolares, a liberdade pedagógica, nos estabelecimentos de ensino particular, fica, na prática, sem qualquer possibilidade de exercício.

O mesmo se vai verificar em relação aos métodos pedagógicos, uma vez que os documentos oficiais, em especial os programas das diferentes disciplinas, em vez de definirem os objectivos a alcançar pelos alunos no fim do ano lectivo ou no fim do ciclo de estudos, prescrevem os conhecimentos a adquirir, indo ao ponto de fixarem os métodos a seguir.

A acrescentar a esta situação é, ainda, de referir a pouca maleabilidade, ou mesmo ausência de maleabilidade, dos currículos escolares, uma vez que estes fixavam para cada disciplina um elevado número de aulas semanais, o que impossibilitava a introdução de novos conteúdos ou mesmo de actividades complementares.

Esta situação impediu as escolas particulares de apresentarem projectos educativos diferenciados dos das escolas oficiais, o que limitou e condicionou a sua capacidade inovadora.

Há, assim, uma excessiva centralização das estruturas educativas em Portugal, o que conduziu a uma total ausência de liberdade pedagógica. 
A este respeito não devemos deixar de citar um texto de Jean Thomas, a propósito da autonomia pedagógica do professor:

«A estas três condições - informação, comunicação, participação - segue-se uma quarta: autonomia pedagógica do docente. Em princípio, ninguém objecta contra ela. É uma questão de medida. A autonomia que temos em vista deve ser extensa. Uma vez que os objectivos de uma reforma foram claramente expostos e que se deram as necessárias directrizes para assegurar uma coesão do sistema é preciso ter confiança nos docentes, cada um na sua aula e todos no seio da sua escola, sob a autoridade do director do estabelecimento, para adaptar o ensino às condições e circunstâncias locais, ao meio ambiente natural, social e cultural, às aptidões e aspirações dos alunos. Mesmo numa organização fortemente especializada não se ganhará seja o que for com a pretensão de querer em cada cidade, vila, aldeia, estabelecimento do mesmo grau, que se façam os mesmo exercícios, que se adoptem os mesmos horários e planos de estudos, que se estudem os mesmos textos. E haverá, em compensação, muito a perder porque é assim que se asfixia a imaginação, se recalca a iniciativa, se cortam as asas à inovação. Que se renuncie, pois, à uniformidade, à rigidez e ao conformismo que subsistem ainda - mesmo que os proíbam - em tantos sistemas escolares. Que se encoraje, na medida do possível e sob todas as formas, a diversidade e a originalidade, fontes de toda a criação» ${ }^{30}$.

Este texto de Jean Thomas aponta assim, por um lado, as obrigações do Estado em relação ao ensino e, por outro, os limites da sua intervenção no que respeita à liberdade pedagógica.

Neste aspecto compete ao Estado definir as estruturas do sistema educativo, os objectivos a atingir pelos alunos nas diferentes modalidades e níveis de ensino, mas o processo de os alcançar pertencerá às diferentes instituições educativas através dum modo participativo.

O Estado, através dos seus órgãos, deverá inspeccionar a qualidade pedagógica dos diferentes estabelecimentos de ensino, enquanto a estes pertence a responsabilidade da sua organização pedagógica ${ }^{31}$.

Outros aspectos, não menos importantes da organização do ensino particular, deverão ser salientados.

Assim:

1. Era livre a fundação de estabelecimentos de ensino particular. No entanto, a sua abertura era precedida da obtenção dum alvará que podia ser recusado desde que, na localidade ou zona urbana em que se pretendia implantar, a população existente não o justificasse ou, desde que o estabelecimento ou estabelecimentos, porventura aí existentes, funcionassem em condições satisfatórias ${ }^{32}$. 
2. Os exames finais de ciclo dos alunos de Ensino Particular eram prestadas perante júris especiais, dos quais faziam obrigatoriamente parte um professor do ensino particular devidamente habilitado e inscrito. As provas eram prestadas no liceu ou escola da zona pedagógica ou, no próprio colégio, desde que para tal autorizado ${ }^{33}$.

Quando o número de alunos examinandos matriculados ou a localização de qualquer estabelecimento de ensino particular o justificasse, podia o Ministro da Educação Nacional, mediante parecer favorável da Direç̧ão Geral do Ensino Liceal e da Inspecção do Ensino Particular, autorizar que os examinandos desse estabelecimento fossem nele sujeitos a exame. Neste caso, a constituição dos júris era idêntica à dos liceus e as provas obedeciam às mesmas normas e tinham os mesmos efeitos que as realizados nos liceus ou escolas técnicas.

Os exames do $3 .^{\circ}$ ciclo eram realizados, apenas, nas escolas oficiais.

3. Para o exercício de funções docentes no ensino particular era exigido diploma ou autorização especial da Inspecção Superior de Ensino Particular e, para a sua obtenção, era necessário provar idoneidade profissional, moral e cívica ${ }^{34}$.

5. Todos os estabelecimentos de ensino particular deviam ter um director responsável, possuidor de um diploma especial ${ }^{35}$.

6. Os directores e professores dos estabelecimentos de ensino particular estavam sujeitos a sanções disciplinares, quando cometessem infracções ou por desrespeito das leis e princípios pedagógicos fundamentais ou por terem dentro ou fora da escola procedimento moral repreensível ${ }^{36}$.

7. Todo o ensino deveria ser orientado pelos princípios da doutrina e moral cristãs. Nas escolas de ensino particular o ensino religioso não dependia de autorização oficial.

Entretanto, começaram a surgir forças tentando incrementar, desenvolver e dignificar o ensino particular.

- O Episcopado Português através duma Nota Pastoral, em 1962, declara que «parece chegada a hora de encarar com vistas largas, o problema do ensino particular, à semelhança de outros países»;

- Nova Nota Pastoral, em 1964, em que se afirma que o Estado tem o direito e o dever de proteger e promover tudo o que respeita à educação;

- Realização do I Congresso Nacional do Ensino Particular, em 1965, em que, além de evidenciar as preocupações pedagógicas do ensino particular e de se demarcar das escolas particulares do ensino clandestino, em que se transformou grande parte dos ensinos individual e doméstico, impõe que o ensino particular tem direitos e solicita apoio financeiro do Estado. 
Assim:

- O ensino particular presta um serviço de interesse nacional, paralelamente com o ensino oficial. Só o Estado pode garantir as condições gerais em que o ensino particular goze das possibilidades e prestígio a que tem direito.

$\mathrm{Na}$ legislação fundamental - Constituição e Concordata —, o Ensino Particular tem um justo lugar. Na legislação de aplicação, porém, e sobretudo na prática administrativa, os objectivos do Ensino Particular são dificultados e cria-se-lhe uma situação de desfavor. Importava corrigir a situação actual no sentido de:

a) isentar totalmente o Ensino Particular de contribuições e impostos de natureza fiscal;

b) dar apoio financeiro aos estabelecimentos de ensino particular que o requeiram e dele necessitem;

c) equiparar os alunos do Ensino Particular aos do Ensino Oficial, no que respeita a documentação e propinas de matrícula e exame, assim como a dispensa de exame por média;

d) admitir os professores do ensino particular a serviço de exames na zona pedagógica a que pertença o estabelecimento de ensino em que leccionem;

e) constituir os júris de exames que funcionem em escolas de ensino particular, com número igual de professores do ensino particular e do ensino oficial.

f) que da comissão permanente responsável pela aprovação dos livros escolares faça parte um representante do ensino particular.

g) que os estabelecimentos de ensino particular possam ter planos próprios de estudo, com validade oficial.

O Ministro da Educação de então, Professor Galvão Teles, em mensagem dirigida ao Presidente do Congresso, Padre Soares Cabeçadas, não deixou de salientar a importância do ensino particular, no contexto do sistema de ensino, ao escrever:

«Ressalta daqui que o Ensino Particular é chamado a colaborar numa alta função, que lhe confere especial dignidade e, se lhe outorga direitos, também lhe impõe deveres. Não se estranhe o teor da frase, porque - sem menosprezar embora os direitos - é realmente nos deveres que recai o acento tónico, trate-se do Ensino Público, ou do Particular.

Ensinar, educar, mais do que qualquer outra actividade de utilidade pública, exige um espírito de devoção, de dádiva, de desinteresse, uma noção de responsabilidade, que nunca será demais pôr em relevo. Educar é um acto de entrega, uma missão, um sacerdócio, que nenhuma sombra pode toldar.

Das minhas palavras ressalta também que nem o ensino privado deve assumir uma atitude de hostilidade ou má-vontade contra o ensino estadual, nem este con- 
tra aquele, sendo criticável tudo o que se filie nessa postura ou contenha ressaibos de antagonismo inexistente. $O$ importante é que, em ambos os sectores integrados na mesma solidária harmonia de conjunto, cada um cumpra o melhor que em suas forças caiba» ${ }^{37}$.

Este reconhecimento da importância do ensino particular está patente no Projecto da Proposta de Lei . $^{\circ}$ 4/IX - III Plano de Fomento - para 1968-1973, onde podemos ler:

«Pretende-se dar ao ensino particular papel mais importante dentro de um sistema nacional de educação. É a essa luz que se encara designadamente, como política a intensificar, a concessão de benefícios ou vantagens no tocante a instalação e funcionamento de estabelecimentos de ensino particular, com o objectivo de poder vir a tornar esse ensino tão acessível como o público — pelo menos para os economicamente carecidos - e assim, mediante a igualação ou aproximação de custos, proporcionar aos interessados real liberdade na opção a fazer. Por essa via, fomentar-se-á o alargamento da rede escolar (de forma menos trabalhosa e menos onerosa para o Estado), facilitar-se-á a escolha entre as duas modalidades de ensino e realizar-se-á, ao mesmo tempo, um fim de acção social escolar. Integra-se neste pensamento a Portaria n. 20 904, de 13 de Novembro de 1964, que regula a concessão de subsídios para a construção de edifícios destinados ao ensino particular. Outras providências, cujo estudo está desde já a merecer as atenções do Governo, são as tendentes a facilitar o recurso ao crédito e criar incentivos fiscais neste domínio» ${ }^{38}$.

\subsection{Projecto do Ministro Galvão Teles}

Numa comunicação ao País, em 16 de Dezembro de 1966, de novo o Ministro da Educação, Professor Doutor Inocêncio Galvão Teles ${ }^{39}$, ao referir-se ao ensino particular, anunciava que a sua regulamentação passaria a ser dominada «por espírito mais aberto que o da legislação vigente, dentro da preocupação de o integrar ou assimilar verdadeiramente num sistema nacional de educação».

E acrescentava:

«A legislação vigente considera o ensino particular como uma função pública, mas só para o efeito dos deveres ou responsabilidades. Esta incongruente limitação (...) desaparece no texto do projecto».

Neste, aproxima-se mais o ensino particular do público, procurando estabelecer entre eles um certo paralelismo de direitos e de deveres, sem no entanto desprezar as diferenças de natureza que entre eles existem, e sem esquecer também as prerrogativas soberanas em que se encontra investido o Estado e que 
lhe impõem especiais ónus, como também lhe conferem os correspondentes poderes $^{40}$.

Por outro lado, o Ministro da Educação previa a concessão ao ensino particular de subsídios destinados à instalação ou funcionamento dos estabelecimentos de ensino, no sentido de tornar esta modalidade de ensino tão acessivel como o público, e assim, mediante a igualação ou aproximação de custos, proporcionar aos interessados uma real liberdade na escolha ou opção a fazer.

E concluía:

«Prevê-se que os estabelecimentos de ensino particular que reúnam certas condições possam ser declarados de utilidade pública, com largos e importantes benefícios, ou oficializados, o que lhes permitirá conferir diplomas nos mesmos termos em que os estabelecimentos públicos o fazem. Também se prevêem formas de colaboração entre o Estado e os estabelecimentos particulares, através da celebração de contratos particulares, geradores de situações jurídicas diversas, contratos de que se estabelecem alguns modelos, sem carácter taxativo» ${ }^{41}$.

O primeiro passo encontra-se no Projecto do Estatuto da Educação Nacional, do Ministro da Educação Professor Doutor Galvão Teles.

Neste documento adoptou-se uma atitude pluralista quanto à titularidade dos poderes e deveres educacionais - os pais ${ }^{42}$, a Igreja (nos termos da Concordata, de 7 de Maio de 1940) ${ }^{43}$ e o Estado, particularmente na sua função coordenadora e supletiva ${ }^{44}$.

Daqui resulta o princípio do reconhecimento da liberdade de ensino: «é reconhecida a liberdade de ensino de qualquer grau ou ramo, em desenvolvimento dos princípios consignados na Lei n. $^{\circ} 2033$, de 27 de Junho de 1949 e na Concordata com a Santa Sé. O ensino particular desempenha no seu conjunto uma função de interesse público».

A todos era reconhecido o direito de acesso à cultura, independentemente da sua condição social e económica ${ }^{45}$. O ensino particular, globalmente considerado, desempenhará uma função de interesse público ${ }^{46}$, sendo-lhe reconhecida para efeitos de exame a frequência nos respectivos estabelecimentos ${ }^{47} \mathrm{e}$ a liberdade na fixação de planos de estudos ${ }^{48}$.

Os estabelecimentos particulares podiam gozar dos direitos de livre organização, livre escolha de docentes, assistência pública e outros estabelecidos em lei ou contrato ${ }^{49}$, embora estivessem sujeitos à orientação e fiscalização do Estado ${ }^{50}$.

O Projecto de Estatuto admitia a possibilidade de oficialização de estabelecimentos particulares de ensino ${ }^{5 !}$, ou mesmo a sua elevação a estabelecimentos particulares de utilidade pública ${ }^{52}$ e a sua integração no ensino público ${ }^{53}$; podendo, ainda, uma entidade privada ser concessionária da gestão de um estabelecimento público $^{54}$, entre outras modalidades de colaboração estabelecidas ${ }^{55}$. 
Podia, ainda, ser-lhes atribuído um conjunto de benefícios, dos quais destacaremos a isenção de impostos, a concessão de créditos a longo prazo, sem juros ou com juros módicos e a concessão de subsídios pelo Ministério da Educação Nacional $^{56}$.

Do mesmo modo, as disposições gerais sobre o pessoal docente se aplicavam, igualmente, aos professores do ensino público e do ensino privado ${ }^{57}$.

Isto não implicava, no entanto, a inexistência de um certo número de condicionantes como, por exemplo: a reserva da designação de liceu a estabelecimentos públicos, devendo os secundários particulares designar-se de colégios ${ }^{58}$, a possibilidade de encerramento por decisão ministerial passível de recurso ${ }^{59}$ e a necessidade de aprovação prévia do projecto dos edifícios ${ }^{60}$.

Este projecto que, afinal, não deu frutos, anuncia, de certa maneira, o crepúsculo do longo período iniciado em 1939, em que se promoveu um ensino livre de intenção, mas em que o ensino oficial dominava, por completo, o privado.

O projecto do Ministro Galvão Teles revela uma grande receptividade aos problemas da liberdade de ensino, receptividade que parecia aumentar à medida que se ia realizando uma certa mudança, em sentido pluralista, nos rumos da cultura nacional.

Esta previsão não veio a confirmar-se no Projecto do Sistema Escolar do Ministro da Educação Professor Doutor Veiga Simão, eivado, de novo, de um certo estatismo.

\subsection{Projecto do Ministro Veiga Simão}

O Projecto do Sistema Escolar é um diploma concebido em termos de ensino oficial, levando a supor que, a curto ou longo prazo, todo o ensino se viria a converter em monopólio do Estado, uma vez que não contém qualquer referência ao regime das instituições escolares privadas.

Isto não significa que alguns dos seus princípios - «diversificação do sistema escolar, permeabilidade e inter-relação entre as diversas modalidades e graus de ensino e a preocupação em implementar um ensino integrado» — não levassem a respeitar uma legítima autonomia dos estabelecimentos de ensino particular, integrando-os no sistema.

Uma referência individualizada e específica em relação ao ensino privado é feita a propósito da formação profissional, matéria em que o Ministério da Educação oferece a colaboração a todas as iniciativas, tanto no âmbito do sector público como no do privado.

Posteriormente, numa Comunicação ao País, em 25 de Janeiro de 1972, o Ministro da Educação Nacional, Professor Doutor Veiga Simão, referindo-se «à 
integração do ensino particular na rede escolar do País e à urgente necessidade de se promulgar um novo estatuto para esse ramo de ensino e revelando ter a consciência de que muitos estabelecimentos defrontam dificuldades económicas acentuadas, declarou ir acorrer às situações mais prementes, sobretudo nas zonas desprovidas de escolas oficiais do ensino secundário, tendo para isso inscrito uma verba de 60000 contos».

No entanto, nada foi dito quanto à natureza da integração do ensino particular, nem às orientações gerais do futuro estatuto.

Mais tarde, em Setembro de $1972^{61}$, o Professor Veiga Simão, ao reafirmar o empenhamento do Governo «numa ampla e profunda reforma do sistema educacional português, sublinhou que a actividade das instituições particulares de ensino seria devidamente considerada nas estruturas e nas acções resultantes da citada reforma, visando um planeamento global da educação de todos os portugueses».

Esta orientação teria em conta «o princípio constitucional da liberdade de ensino e a imperiosa necessidade de um aproveitamento integral de todos os meios humanos, materiais e financeiros disponíveis, sejam públicos ou particulares, e constitui, por outro lado, o reconhecimento do Governo pela valiosa e decisiva contribuição que a iniciativa privada tem prestado no sector da educação».

E acrescenta: «há que rever com a maior urgência os moldes em que se deverá concretizar a integração do ensino particular nas novas estruturas da educação nacional».

Assim, foram anunciadas várias iniciativas que constituíram um primeiro passo com vista a rever a situação do ensino particular no quadro do sistema educativo.

De entre as iniciativas anunciadas salientamos:

- criação dum grupo de trabalho constituído por representantes dos diversos órgãos centrais do Ministério da Educação Nacional, do Grémio Nacional dos Proprietários de Estabelecimentos de Ensino Particular, do Sindicato Nacional dos Professores do Ensino Particular, da Igreja Católica e individualidades de reconhecido mérito a quem seria confiado a elaboração do projecto de um novo estatuto para o Ensino Particular;

- defesa da qualidade do ensino ministrado através das seguintes medidas:

a) repressão do ensino particular clandestino;

b) análise e fiscalização do ensino e das condições em que é ministrado;

c) normas a adoptar na avaliação do aproveitamento dos alunos.

Para a concretização destes objectivos estava prevista a reestruturação da Inspecção Geral do Ensino Particular. 
d) alargamento aos estabelecimentos de ensino particular da rede escolar de ensino obrigatório.

Como o Governo tinha garantido a escolaridade obrigatória de seis anos sendo o $5 .^{\circ}$ e $6 .^{\circ}$ anos leccionados através do Ciclo Preparatório do Ensino Secundário - , gratuita a partir de $1972-73^{62} \mathrm{e}$, como nem todos os concelhos estavam dotados com escolas de ensino oficial, o Ministério da Educação Nacional teve de assegurar o seu cumprimento através do recurso aos estabelecimentos de ensino particular aí existentes.

Para o efeito, seria atribuído um subsídio, por cada um dos alunos matriculados nos referidos estabelecimento de ensino particular, desde que se comprometessem a aceitar a inscrição de todos os alunos que o desejassem, até ao limite da capacidade das suas instalações.

Os encargos com esta iniciativa foram da ordem dos 7000 contos.

- incremento dos postos de recepção do ciclo preparatório TV particular para os quais estavam previstas as seguintes modalidades de apoio:

a) subsídio a alunos para pagamento total ou parcial de propinas e/ou transportes;

b) subsídio aos postos em situação deficitária por não terem atingido a máxima capacidade de frequência ou, tendo-a atingido, que não tivessem receita suficiente para se manterem;

- apoio financeiro ao funcionamento de instalações particulares de ensino secundário.

Neste domínio e, referentes ao ano lectivo de 1971-72, foram atribuídos subsídios que totalizaram 17247,5 contos.

No que respeitou ao ano lectivo de 1972-73, o Ministério da Educação Nacional atribuiu subsídios no montante global de 30000 contos.

E concluía a Nota Oficiosa: «Pela primeira vez, e apesar das limitadas possibilidades do Ministério da Educação Nacional, foi possível realizar um esforço financeiro que totaliza mais de 65000 contos a favor do ensino particular na Metrópole».

Em Março de 1974, na sessão de encerramento do III Encontro Nacional de Responsáveis do Ensino Particular, o Ministro Veiga Simão salientou que nesse ano 306 escolas particulares estavam a ser subsidiadas ( $+/-135000$ contos) e que o projecto do novo Estatuto constituíria um «avanço notável no que respeita ao apoio ao Ensino Particular, não apenas como ensino supletivo, mas em condições não só de igualdade mas também de idênticas responsabilidades com o ensino oficial». 
Entretanto, com o 25 de Abril de 1974, novos rumos e até, de certo modo, novas sombras, iriam pairar sobre o ensino secundário particular.

\section{FREQUÊNCIA DO ENSINO PARTICULAR}

\subsection{Período de 1950-51 a 1959-60}

A análise do Quadro I revela-nos,desde logo, que a população escolar do ensino secundário liceal, em 1959-60, é superior ao dobro da registada em 1950-51.

Este acréscimo não se vai repartir, igualmente, pelo ensino oficial e particular, uma vez que os alunos que frequentavam o ensino particular representavam mais de $50 \%$ do total da população do ensino liceal, posição que se foi reforçando ao longo dos anos.

\section{QUADRO I}

FREQUÊNCIA GLOBAL DO ENSINO SECUNDÁRIO

(OFICIAL E PARTICULAR) ${ }^{63}$

(1950/51-1959/60)

\begin{tabular}{|c|c|c|c|c|c|c|}
\hline \multirow{2}{*}{ ANOS } & \multicolumn{2}{|c|}{ Total Geral } & \multicolumn{2}{c|}{ Oficial } & \multicolumn{2}{c|}{ Particular } \\
\cline { 2 - 7 } & N. ${ }^{\circ}$ & Índice & Total & Índice & Total & Índice \\
\hline $1950-51$ & 48485 & 100 & 21962 & 100 & 26523 & 100 \\
$1951-52$ & 51577 & 106 & 23677 & 108 & 27900 & 105 \\
$1952-53$ & 54370 & 112 & 24909 & 113 & 29461 & 111 \\
$1953-54$ & 58721 & 121 & 26645 & 121 & 32076 & 121 \\
$1954-55$ & 62680 & 129 & 27930 & 127 & 34750 & 131 \\
$1955-56$ & 68873 & 142 & 30951 & 141 & 37922 & 143 \\
$1956-57$ & 76637 & 158 & 31896 & 145 & 44741 & 169 \\
$1957-58$ & 82962 & 171 & 34812 & 159 & 48150 & 182 \\
$1958-59$ & 91020 & 188 & 37859 & 172 & 53161 & 200 \\
$1959-60$ & 101969 & 210 & 42049 & 191 & 59920 & 226 \\
\hline
\end{tabular}

Assim:

A percentagem dos alunos que frequentaram o ensino particular, em relação ao número total de alunos, é-nos dado pelo seguinte quadro: 


\section{QUADRO II \\ FREQUÊNCIA DOS ALUNO DO ENSINO PARTICULAR \\ $(1950 / 51-1959 / 60)$}

\begin{tabular}{|c|c|}
\hline Anos Lectivos & $\%$ \\
\hline $1950-51$ & 54,7 \\
$1951-52$ & 54,1 \\
$1952-53$ & 54,2 \\
$1953-54$ & 54,6 \\
$1954-55$ & 55,4 \\
$1955-56$ & 55,1 \\
$1956-57$ & 58,4 \\
$1957-58$ & 58,0 \\
$1958-59$ & 58,4 \\
$1959-60$ & 58,8 \\
\hline
\end{tabular}

Vários motivos poderão explicar tais variações percentuais.

Assim:

- a existência de liceus apenas em cidades ou em áreas de influência populacional das grandes cidades, caso de Oeiras e Póvoa de Varzim;

- insuficiência de instalações dos liceus em funcionamento;

- rede escolar diversificada de estabelecimentos de ensino particular espalhada pelo País;

- elevado número de alunos que, no decurso do ano lectivo, abandonam os liceus, tentando obter nos estabelecimentos de ensino particular a aprovação que dificilmente alcançariam nos liceus e o facto de só poderem ser admitidos, de novo, no liceu após terem concluído o ciclo respectivo;

- ausência duma rede de transportes escolares.

Passemos, agora, a analisar a evolução da frequência escolar no ensino secundário técnico.

Quanto à evolução da frequência escolar do ensino técnico, a partir da década de 50, constata-se que é dos ramos de ensino o que apresenta um crescimento mais progressivo.

A procura do ensino técnico pelos alunos, durante a década de 50, parece corresponder à necessidade de desenvolvimento económico do País - procura de 
técnicos e operários devidamente qualificados. Por outro lado, o ensino técnico, pelos cursos diversificados que apresenta, permitia aos jovens que o frequentavam uma mais rápida e qualificada entrada no mundo do trabalho.

A estas razões se deve juntar, ainda, a disseminação das escolas técnicas pelo País, o que não acontecia com o ramo liceal e a alta taxa de aprovação nos exames de admissão ao ensino técnico.

Atentemos, pois, no quadro seguinte:

\section{QUADRO III \\ FREQUÊNCIA DO ENSINO TÉCNICO \\ $(1950 / 51-1959 / 60)$}

\begin{tabular}{|c|c|c|c|c|c|c|}
\hline \multirow{2}{*}{ ANOS } & \multicolumn{2}{|c|}{ Total Geral } & \multicolumn{2}{c|}{ Oficial } & \multicolumn{2}{c|}{ Particular } \\
\cline { 2 - 7 } & $\mathrm{N}^{\circ}$ & Índice & Total & Índice & Total & Índice \\
\hline $1950-51$ & 34316 & 100 & 30078 & 100 & 4238 & 100 \\
$1951-52$ & 34676 & 101 & 30160 & 100 & 4516 & 106 \\
$1952-53$ & 35170 & 102 & 30878 & 103 & 4292 & 101 \\
$1953-54$ & 38255 & 111 & 34084 & 113 & 4171 & 98 \\
$1954-55$ & 41648 & 121 & 37903 & 126 & 3745 & 90 \\
$1955-56$ & 47825 & 139 & 43630 & 145 & 4195 & 99 \\
$1956-57$ & 53968 & 157 & 49376 & 164 & 4592 & 108 \\
$1957-58$ & & & & & & \\
$1958-59$ & 71575 & 209 & 66689 & 222 & 4886 & 115 \\
$1959-60$ & 83507 & 243 & 77716 & 258 & 5791 & 137 \\
\hline
\end{tabular}

O quadro revela que a frequência escolar global, em 1959-60, duplicou em relação à de 1950-51, o que se ficou a dever, sobretudo, ao ensino oficial, uma vez que a do ensino particular apresentou uma evolução muito modesta.

Esta situação deve-se ao facto das entidades privadas não se arriscarem a montar estabelecimentos, para esta modalidade de ensino, uma vez que tal empreendimento era bastante oneroso e pouco lucrativo. 
Os alunos inscritos no Ciclo Preparatório, no período de 1950-51 a 1959-60, foram os seguintes:

QUADRO IV

FREQUÊNCIA DO CICLO PREPARATÓRIO DO ENSINO TÉCNICO

(1950/51-1959/60)

\begin{tabular}{|c|c|c|c|c|c|c|}
\hline \multirow{2}{*}{$\begin{array}{c}\text { Anos } \\
\text { Lectivos }\end{array}$} & \multicolumn{7}{|c|}{ Ciclo Preparatório } \\
\cline { 2 - 7 } & Total & Índice & Oficial & Indice & Partic. & Índice \\
\hline $1950-51$ & 7351 & 100 & 6586 & 100 & 765 & 100 \\
$1951-52$ & 8113 & 110 & 7296 & 110 & 817 & 107 \\
$1952-53$ & 10492 & 143 & 9332 & 142 & 1160 & 152 \\
$1953-54$ & 12713 & 173 & 11463 & 174 & 1250 & 163 \\
$1954-55$ & 14641 & 199 & 13296 & 202 & 1345 & 176 \\
$1955-56$ & 17196 & 234 & 15588 & 237 & 1608 & 210 \\
$1956-57$ & 20020 & 272 & 18197 & 276 & 1823 & 238 \\
$1957-58$ & & & & & & \\
$1958-59$ & 28070 & 382 & 25829 & 392 & 2241 & 293 \\
$1959-60$ & 32742 & 445 & 30271 & 460 & 2471 & 323 \\
\hline
\end{tabular}

O Ciclo Preparatório apresenta, nos primeiros anos, valores de frequência muito baixos, o que se deve explicar pela sua recente criação (1947-48).

No entanto, a inauguração de novas escolas e a introdução, em muitas outras, do Ciclo Preparatório contribuiu decisivamente para o crescimento da sua frequência nos finais da década.

Dos ramos do ensino técnico — comercial e industrial —, o ramo comercial é o que apresenta uma frequência maior, embora seguida de perto pelo ensino industrial. 
QUADRO V

FREQUÊNCIA DO ENSINO TÉCNICO

(1950/51-1959/60)

\begin{tabular}{|c|c|c|c|c|c|c|c|c|c|c|c|c|}
\hline \multirow{3}{*}{$\begin{array}{c}\text { Anos } \\
\text { Lectivos }\end{array}$} & \multicolumn{6}{|c|}{ Curso Comercial } & \multicolumn{6}{|c|}{ Curso Industrial } \\
\hline & \multirow{2}{*}{$\begin{array}{l}\text { Total } \\
\text { Geral }\end{array}$} & \multirow{2}{*}{ Índice } & \multicolumn{2}{|c|}{ Oficial } & \multicolumn{2}{|c|}{ Particular } & \multirow{2}{*}{$\begin{array}{l}\text { Total } \\
\text { Geral }\end{array}$} & \multirow{2}{*}{ Índice } & \multicolumn{2}{|c|}{ Oficial } & \multicolumn{2}{|c|}{ Particular } \\
\hline & & & Total & Îndice & Total & Índice & & & Total & Índice & Total & Índice \\
\hline $1950-51$ & 15382 & 100 & 12712 & 100 & 2670 & 100 & 11583 & 100 & 10780 & 100 & 803 & 100 \\
\hline $1951-52$ & 15110 & 98 & 12454 & 98 & 2656 & 99 & 11453 & 99 & 10410 & 97 & 1043 & 130 \\
\hline $1952-53$ & 14400 & 94 & 11826 & 93 & 2574 & 96 & 10278 & 89 & 9720 & 90 & 558 & 69 \\
\hline 1953-54 & 15267 & 99 & 12838 & 101 & 2429 & 91 & 10275 & 89 & 9783 & 91 & 492 & 61 \\
\hline $1954-55$ & 15864 & 103 & 13990 & 110 & 1874 & 70 & 11143 & 110 & 10617 & 98 & 526 & 66 \\
\hline $1955-56$ & 17812 & 116 & 15692 & 123 & 2120 & 79 & 12817 & 125 & 12350 & 115 & 467 & 58 \\
\hline $1956-57$ & 19508 & 129 & 17245 & 136 & 2263 & 85 & 14440 & & 13934 & 129 & 506 & 63 \\
\hline $1957-58$ & & & & & & & & & & & & \\
\hline $1958-59$ & 24334 & 158 & 22100 & 174 & 2234 & 84 & 19171 & 166 & 18760 & 174 & 411 & 51 \\
\hline $1959-60$ & 27919 & 182 & 25638 & 202 & 2281 & 85 & 22846 & 197 & 21807 & 202 & 1039 & 129 \\
\hline
\end{tabular}

No que respeita ao ensino particular - o ramo comercial apresentou um declínio na frequência, passando de 2670 alunos em 1950-51 para 2281 em 1959-60.

A frequência do ramo industrial também diminuiu, ao longo da década, com uma inversão, no ano lectivo de 1959-60, em que atingiu 1039 alunos.

Esta baixa de frequência, nos primeiros anos da década, poderá explicar-se não só por razões de ordem demográfica, mas por motivos ligados à aplicação da Reforma de 1948, dos quais podemos destacar: acréscimo de custos do ensino técnico e maior dificuldade de sucesso rápido, resultante do aumento de anos da escolaridade.

Esta tendência vai inverter-se a partir do ano lectivo de 1953-54, inicialmente de um modo lento mas, após o ano lectivo de 1958-59, de um modo mais acentuado.

$\mathrm{Na}$ origem deste movimento ascensional da frequência deverá apontar-se o alargamento da rede escolar e a subida acentuada do crescimento económico geradora, por sua vez, duma diminuição de custos do ensino e melhoria do nível de vida das famílias.

A reduzida frequência no ensino particular - comercial e industrial - deve relacionar-se, por um lado, com o nível socioeconómico dos alunos que o frequentam e, por outro lado, com os elevados investimentos que a fundação dum estabelecimento particular do ensino técnico acarretava ${ }^{64}$. 


\subsection{Período de 1960-61 a 1970-71}

Globalmente a frequência do ensino secundário particular, ao longo da década de 60 , é a que se apresenta no quadro seguinte:

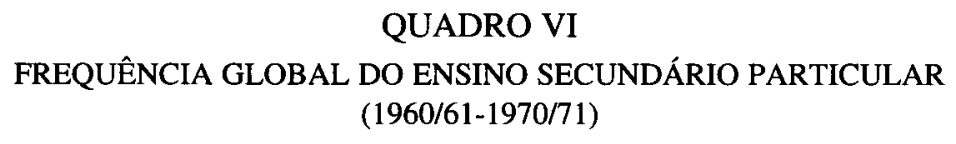

\begin{tabular}{|c|r|c|c|c|c|c|c|c|}
\hline \multirow{2}{*}{$\begin{array}{c}\text { Anos } \\
\text { Lectivos }\end{array}$} & \multicolumn{9}{|c|}{ Alunos } & \multicolumn{2}{c|}{$\begin{array}{c}\text { Variação } \\
\%\end{array}$} \\
\cline { 4 - 8 } & $\begin{array}{c}\text { Total } \\
\text { Geral }\end{array}$ & \multirow{2}{*}{ Índice } & \multicolumn{2}{|c|}{ Ens. Liceal } & \multicolumn{2}{|c|}{ Ens. Técnico } & \multicolumn{2}{|c|}{} \\
\cline { 4 - 8 } & & Total & Índice & Total & Índice & Liceal & Técn. \\
\hline $1960-61$ & 71223 & 100 & 65761 & 100 & 5462 & 100 & 92,33 & 7,67 \\
$1961-62$ & 74932 & 105 & 68976 & 105 & 5956 & 109 & 92,05 & 7,95 \\
$1962-63$ & 82119 & 115 & 75507 & 115 & 6612 & 121 & 91,95 & 8,05 \\
$1963-64$ & 88389 & 124 & 81254 & 124 & 7135 & 131 & 91,33 & 8,07 \\
$1964-65$ & 92942 & 130 & 84877 & 129 & 8065 & 148 & 91,32 & 8,68 \\
$1965-66$ & 96779 & 136 & 87697 & 133 & 9082 & 166 & 90,62 & 9,38 \\
$1966-67$ & 98143 & 138 & 89054 & 135 & 9189 & 168 & 90,65 & 9,35 \\
$1967-68$ & 100469 & 141 & 90660 & 138 & 9809 & 180 & 90,24 & 9,76 \\
$1968-69$ & 94137 & 132 & 84940 & 129 & 9197 & 168 & 90,23 & 9,77 \\
$1969-70$ & 73305 & 103 & 66460 & 101 & 6845 & 125 & 90,66 & 9,34 \\
$1970-71$ & 79161 & 111 & 72033 & 110 & 7128 & 131 & 91,00 & 9,00 \\
\hline
\end{tabular}

A análise do quadro dá-nos a conhecer um período de explosão escolar do ensino particular, que corresponde à primeira parte da década de 60 , uma vez que o ensino oficial, apenas se encontrando sedeado nas capitais de distrito, reduz a sua acção a áreas limitadas de território.

Assim, em muitas localidades do País, especialmente nas vilas, nasceram estabelecimentos de ensino particular que, embora onerosos para as famílias, representavam a única porta aberta para a educação.

Além disso, a explosão escolar revelou a incapacidade dos liceus para resolverem o problema da procura do ensino transformando-se, muitos deles, em armazéns de alunos impedindo, assim, qualquer convivência entre eles ${ }^{65}$.

A década de 60 é, de novo, um período em que o ensino particular continua a ter, em termos quantitativos, maior peso que o ensino oficial.

A quebra de frequência que se verifica na globalidade do ensino liceal, a par204 tir do ano lectivo de 1968-69, corresponde ao lançamento e implementação do 
Ciclo Preparatório do Ensino Secundário, com a consequente extinção do $1 .^{\circ}$ Ciclo Liceal e Ciclo Preparatório do Ensino Técnico e arranque de um plano de cobertura do país com escolas preparatórias, postos da telescola e aumento de escolas secundárias, o que vai pôr em causa a sobrevivência de muitos estabelecimentos de ensino particular, em inúmeras localidades.

Esta situação levou a que muitos proprietários e directores de colégios negociassem as suas instalações com o Estado.

É neste período que, nas grandes cidades, o ensino público, devido à explosão escolar, perde qualidade pedagógica e o ensino particular naturalmente se desenvolve.

Esta situação pode, igualmente, ser constatada no quadro que a seguir se apresenta, referente à frequência escolar do Curso Geral e do Curso Complementar:

\section{QUADRO VII}

FREQUÊNCIA DO ENSINO LICEAL (OFICIAL E PARTICULAR)

$(1960 / 61-1970 / 71)$

\begin{tabular}{|c|r|r|r|r|r|r|r|r|r|r|}
\hline \multirow{2}{*}{$\begin{array}{c}\text { Anos } \\
\text { Lectivos }\end{array}$} & \multicolumn{5}{|c|}{ Curso Geral } & \multicolumn{5}{c|}{ Curso Complementar } \\
\cline { 2 - 11 } & \multicolumn{1}{|c|}{ Total } & Oficial & Part. & $\%$ Of. & \% Part. & Total & Oficial & Part. & $\%$ Of. & $\%$ Part. \\
\hline $1960-61$ & 95944 & 39131 & 56813 & 40,79 & 59,21 & 15877 & 6929 & 8948 & 43,64 & 56,36 \\
$1961-62$ & 101585 & 41874 & 59711 & 41,22 & 58,78 & 16665 & 7400 & 9265 & 44,40 & 55,60 \\
$1962-63$ & 110572 & 45701 & 64871 & 41,33 & 58,67 & 18866 & 8231 & 10636 & 43,63 & 56,37 \\
$1963-64$ & 118086 & 48433 & 69653 & 41,01 & 58,99 & 21057 & 9456 & 11601 & 44,91 & 55,09 \\
$1964-65$ & 120586 & 49540 & 71046 & 41,08 & 58,92 & 24071 & 10240 & 13831 & 42,54 & 57,46 \\
$1965-66$ & 124622 & 51180 & 73442 & 41,07 & 58,93 & 25111 & 10856 & 14255 & 43,23 & 56,77 \\
$1966-67$ & 128563 & 54478 & 74085 & 42,37 & 57,63 & 26882 & 11913 & 14969 & 44,32 & 55,68 \\
$1967-68$ & 133465 & 57605 & 75860 & 43,16 & 56,84 & 26837 & 12037 & 14800 & 44,85 & 55,15 \\
$1968-69$ & 115465 & 46390 & 69462 & 40,04 & 59,96 & 28118 & 12640 & 15478 & 44,95 & 55,05 \\
$1969-70$ & 89368 & 39043 & 50325 & 43,69 & 56,31 & 31005 & 14870 & 16135 & 47,96 & 52,04 \\
$1970-71$ & 101019 & 47263 & 53756 & 46,79 & 53,21 & 36240 & 17963 & 18277 & 49,57 & 50,43 \\
\hline
\end{tabular}

No que respeita ao ensino técnico a análise do Quadro VI revela, também, que a percentagem de alunos inscritos no ensino particular, em relação ao ensino oficial, oscilou entre 7,67\% em 1960-61 e 9,77\% em 1968-69, o que mostra que esta modalidade de ensino era quase, exclusivamente, de índole oficial.

Esta situação explica-se pelo carácter oneroso desta modalidade de ensino, resultante dos vultuosos investimentos que os estabelecimentos de ensino particular tinham de realizar para a instalação e equipamento das suas oficinas. 


\section{PROFESSORES E RELAÇÃO PROFESSOR/ALUNO}

Embora se não disponha de dados objectivos quanto à evolução do corpo docente, nos estabelecimentos de ensino particular, na década de 1950-60, a análise do Quadro VIII mostra que, na década seguinte 1960-70, se verificou, em termos quantitativos, uma certa estabilidade.

\section{QUADRO VIII \\ ENSINO LICEAL}

ESTABELECIMENTOS, PROFESSORES E RELAÇÃO PROFESSOR/ALUNO (1960/61-1973/74)

\begin{tabular}{|c|c|c|c|c|c|c|c|c|c|}
\hline \multirow{2}{*}{$\begin{array}{c}\text { Anos } \\
\text { Lectivos }\end{array}$} & \multicolumn{3}{|c|}{ Total } & \multicolumn{6}{c|}{ Ensino Liceal } \\
\cline { 4 - 9 } & Estabel. & Prof. & $\begin{array}{c}\text { Relação } \\
\text { Prof./Aluno }\end{array}$ & Estabel. & Prof. & $\begin{array}{c}\text { Relação } \\
\text { Prof./Aluno }\end{array}$ & Estabel. & Prof. & $\begin{array}{c}\text { Relação } \\
\text { Prof./Aluno }\end{array}$ \\
\hline $1960-61$ & 385 & 5702 & 19,6 & 43 & 2072 & 22,2 & 342 & 3630 & 18,1 \\
$1961-62$ & 390 & 5757 & 20,5 & 43 & 2240 & 22,0 & 347 & 3517 & 19,6 \\
$1962-63$ & 426 & 6433 & 20,1 & 43 & 2413 & 22,4 & 383 & 4020 & 18,8 \\
$1963-64$ & 442 & 6782 & 20,5 & 43 & 2574 & 22,5 & 399 & 4208 & 19,3 \\
$1964-65$ & 446 & 6965 & 20,8 & 45 & 2715 & 22,0 & 401 & 4250 & 20,0 \\
$1965-66$ & 443 & 7145 & 21,0 & 45 & 2825 & 22,0 & 398 & 4320 & 20,3 \\
$1966-67$ & 453 & 7141 & 21,8 & 47 & 2934 & 22,6 & 406 & 4207 & 21,2 \\
$1967-68$ & 458 & 7361 & 21,8 & 47 & 3339 & 20,8 & 411 & 4022 & 22,5 \\
$1968-69$ & 457 & 7548 & 19,1 & 49 & 3067 & 19,2 & 408 & 4481 & 19,0 \\
$1969-70$ & 438 & 7225 & 16,7 & 51 & 3114 & 17,3 & 387 & 4111 & 16,2 \\
$1970-71$ & 452 & 7436 & 18,5 & 70 & 3365 & 19,4 & 382 & 4071 & 17,7 \\
$1971-72$ & 488 & 8328 & 18,7 & 89 & 4336 & 18,2 & 399 & 3992 & 19,2 \\
$1972-73$ & 461 & 9138 & 19,5 & 119 & 5648 & 17,6 & 342 & 3490 & 22,6 \\
$1973-74$ & & 10172 & 15,7 & & 6249 & 20,3 & & 3923 & 18,3 \\
\hline
\end{tabular}

Como o número de professores não acompanhou o ritmo de crescimento dos alunos no ramo do ensino liceal, a relação professor/aluno apresenta valores variáveis, atingindo 22,5 no ano lectivo de 1967-68, com as inevitáveis repercussões no rendimento escolar.

No ramo do ensino técnico a relação professor/aluno oscilou entre 18,6 (anos 206 lectivos de 1960-61 e 1963-64) e 28,1 (ano lectivo 1969-70). 


\section{QUADRO IX}

ENSINO TÉCNICO-PROFISSIONAL

ESTABELECIMENTOS, PROFESSORES E RELAÇÃO PROFESSOR/ALUNO

(1960/61-1973/74)

\begin{tabular}{|c|c|c|c|c|c|c|c|c|c|}
\hline \multirow{2}{*}{$\begin{array}{c}\text { Anos } \\
\text { Lectivos }\end{array}$} & \multicolumn{3}{|c|}{ Total } & \multicolumn{6}{|c|}{ Ensino Liceal } \\
\cline { 5 - 9 } & \multicolumn{3}{|c|}{} & \multicolumn{3}{|c|}{ Oficial } & \multicolumn{3}{|c|}{ Particular } \\
\cline { 2 - 9 } & Estabel. & Prof. & $\begin{array}{c}\text { Relação } \\
\text { Prof//Aluno }\end{array}$ & Estabel. & Prof. & $\begin{array}{c}\text { Relação } \\
\text { Prof/Aluno }\end{array}$ & Estabel. & Prof. & $\begin{array}{c}\text { Relação } \\
\text { Prof/Aluno }\end{array}$ \\
\hline $1960-61$ & 260 & 4648 & 20,8 & 213 & 4390 & 21,0 & 47 & 294 & 18,6 \\
$1961-62$ & 352 & 5269 & 21,0 & 292 & 4954 & 21,1 & 60 & 315 & 18,8 \\
$1962-63$ & 398 & 5892 & 20,8 & 341 & 5554 & 21,0 & 57 & 338 & 19,5 \\
$1963-64$ & 353 & 6287 & 21,1 & 294 & 5903 & 21,3 & 59 & 384 & 18,6 \\
$1964-65$ & 398 & 6784 & 21,3 & 329 & 6439 & 21,2 & 69 & 345 & 23,4 \\
$1965-66$ & 432 & 7186 & 21,4 & 361 & 6814 & 21,3 & 71 & 372 & 24,4 \\
$1966-67$ & 388 & 7634 & 20,4 & 314 & 7236 & 20,2 & 74 & 398 & 23,1 \\
$1967-68$ & 384 & 8080 & 19,4 & 309 & 7674 & 19,1 & 75 & 406 & 24,2 \\
$1968-69$ & 327 & 7734 & 17,7 & 271 & 7384 & 17,3 & 56 & 350 & 26,3 \\
$1969-70$ & 236 & 7000 & 17,3 & 211 & 6756 & 16,9 & 25 & 244 & 28,1 \\
$1970-71$ & 231 & 7261 & 17,5 & 206 & 7034 & 17,0 & 25 & 227 & 31,4 \\
$1971-72$ & 212 & 7881 & 16,6 & 188 & 7639 & 16,1 & 24 & 242 & 31,5 \\
$1972-73$ & 190 & 8764 & 16,0 & 170 & 8555 & 15,4 & 20 & 209 & 38,5 \\
$1973-74$ & & 9540 & 14,3 & & 9393 & 14,4 & & 147 & 11,0 \\
\hline
\end{tabular}

No que respeita aos aspectos qualitativos do corpo docente, estes não poderão ser observados em virtude da escassez de elementos estatísticos.

\section{REDE ESCOLAR}

A distribuição da rede escolar do ensino secundário (liceal, técnico e particular) tem sido, ao longo dos anos, bastante irregular, uma vez que são as condições sociais das diferentes regiões e o nível das actividades culturais e económicas a condicionar a sua expansão. Para ilustrar esta afirmação, pode ler-se no estudo sobre o Ciclo Preparatório do Ensino Secundário (1960):

«Presentemente (1958-1959) o ensino secundário é ministrado apenas em 189 concelhos dos 303 em que se divide o território do Continente e Ilhas. Só em 67 concelhos, porém, existem estabelecimentos oficiais, liceus ou escolas técnicas; nos restantes 122 concelhos o ensino secundário é assegurado somente através de estabelecimentos particulares.

Dos 189 concelhos onde é ministrado o ensino secundário, apenas 3 deles não possuem estabelecimentos de ensino particular.

O ensino liceal é ministrado em 187 concelhos e o técnico em 83. 
De ensino liceal existem estabelecimentos oficiais em 30 concelhos e particulares em 186.

Do ensino técnico há estabelecimentos oficiais em 62 concelhos e particulares em 36.

É ministrado exclusivamente o ensino liceal em 106 concelhos e o ensino técnico em 2.

São 81 os concelhos em que se ministram os dois ramos de ensino secundário, liceal e técnico, através da colaboração do ensino oficial e do particular.

Há 114 concelhos onde não existem estabelecimentos escolares de qualquer dos dois ramos de ensino secundário.

Das 30 localidades em que existem liceus oficiais, todas têm também escola técnica oficial, à excepção de 3; há, porém, 37 localidades onde existe escola técnica oficial sem que haja liceu, mas em todas elas, com excepção de 2 , o ensino liceal é assegurado através do ensino particular. Dos 67 concelhos em que existe ensino oficial, em todos, menos 2, tem sido possível aos alunos a escolha do ramo de estudos secundários. Porém, nos restantes 122 concelhos só tem sido possível efectivar-se essa escolha em 19, por serem ainda em número muito reduzido os estabelecimentos particulares onde se ministra o ensino técnico.

Nos 189 concelhos onde é ministrado o ensino secundário, existem 517 estabelecimentos deste ramo de ensino, dos quais 137 oficiais e 434 particulares» ${ }^{66}$.

Deste modo, o ensino particular espalha-se por quase $60 \%$ dos concelhos, sendo em $37 \%$ exclusivamente deste tipo, o que traduz o papel relevante que as escolas particulares têm tido no alargamento do ensino liceal ao longo do País.

Durante a década de 1950-1951 a 1959-1960, o número de estabelecimentos de ensino particular era o seguinte:

\section{QUADRO X \\ ESTABELECIMENTOS DE ENSINO PARTICULAR (1950/51-1960/61)}

\begin{tabular}{|c|c|c|}
\hline \multirow{2}{*}{$\begin{array}{c}\text { Anos } \\
\text { Lectivos }\end{array}$} & \multicolumn{2}{|c|}{ Total Geral } \\
\cline { 2 - 3 } & Liceal & Técnico \\
\hline $1950-51$ & 297 & 109 \\
$1951-52$ & 297 & 111 \\
$1952-53$ & 301 & 110 \\
$1953-54$ & 310 & 112 \\
$1954-55$ & 321 & 107 \\
$1955-56$ & & \\
$1956-57$ & 337 & 104 \\
$1957-58$ & 337 & 95 \\
$1958-59$ & 348 & 96 \\
$1959-60$ & 340 & 90 \\
\hline
\end{tabular}


Nos inícios da década de 70 (1970-71), a rede escolar do ensino secundário continuava a revelar enormes deficiências e insuficiências.

Assim, dos 274 concelhos existentes no Continente constatamos:

a) Do ponto de vista da existência ou não de estabelecimentos de ensino secundário:

1. 56 concelhos (20\%) não possuem qualquer estabelecimento de ensino secundário. Situam-se nas zonas rurais e são, na sua maioria, concelhos predominantemente agrícolas.

2. 111 concelhos $(40 \%)$ com estabelecimentos que ministram apenas e, sobretudo, o curso geral dos liceus e/ou equivalentes cursos técnico-profissionais. São estabelecimentos de ensino particular, localizados em zonas rurais, na sua maior parte concelhos agrícolas.

b) Do ponto de vista da existência ou não dos dois ramos de ensino secundário, ensino liceal e ensino técnico-profissional, só em 98 concelhos (35\%) havia possibilidade de opção e, mesmo assim, limitada por dois motivos:

1. no ensino técnico-profissional raramente coexistem os diferentes subramos;

2. em 41 destes concelhos o ensino liceal é apenas ministrado em estabelecimentos de ensino particular.

c) Do ponto de vista da existência de estabelecimentos públicos (liceus e escolas) e estabelecimentos particulares.

Verifica-se que, dos 218 concelhos com estabelecimentos do ensino secundário de qualquer das modalidades 131 (60\%), têm-nos exclusivamente particulares, 5 exclusivamente públicos $\mathrm{e}$, nos restantes 82 , coexistem as duas modalidades de estabelecimentos.

d) Do ponto de vista da sua distribuição geográfica constatamos:

1. os estabelecimentos do ensino público localizavam-se em centros urbanos:

- os liceus nas cidades e, numa ou noutra vila, como Barreiro, Vila Nova de Famalicão, Santo Tirso ou S. João da Madeira existiam secções liceais;

- as escolas técnicas ou suas secções, nas modalidades de ensino mais ligadas ao comércio ou à indústria, espalhavam-se por todo o País;

- os colégios existiam em quase todas as localidades onde havia estabelecimentos públicos (liceus ou escolas comerciais e/ou industriais).

No que respeita aos Açores e à Madeira, a situação era a seguinte: dos 30 concelhos, 20 não tinham qualquer estabelecimento de ensino secundário, 6 só 
tinham estabelecimentos de ensino particular e 4 concelhos (capitais de distrito) possuíam estabelecimentos públicos e privados.

\section{QUADRO XI}

REDE ESCOLAR

(1970-71)

\begin{tabular}{|c|c|c|c|c|c|c|c|c|c|}
\hline \multirow{3}{*}{ DISTRITOS } & \multicolumn{8}{|c|}{ Número de Concelhos com estabelecimentos } & \multirow{3}{*}{$\begin{array}{c}\text { Número de } \\
\text { Concelhos } \\
\text { sem esta- } \\
\text { belecimentos } \\
\text { de ensino } \\
\text { secundário } \\
\text { (pós-escolar, } \\
\text { obrigatório) }\end{array}$} \\
\hline & \multirow{2}{*}{$\begin{array}{c}\text { Número } \\
\text { total } \\
\text { de } \\
\text { Concelhos }\end{array}$} & \multirow{2}{*}{$\begin{array}{c}\text { Liceus e } \\
\text { escolas } \\
\text { técnicas ou } \\
\text { secções e } \\
\text { particulares }\end{array}$} & \multirow{2}{*}{$\begin{array}{c}\text { Secçōes ou } \\
\text { liceu e } \\
\text { particulares }\end{array}$} & \multirow{2}{*}{$\begin{array}{l}\text { Liceus e } \\
\text { escolas } \\
\text { técnicas } \\
\text { e/ou } \\
\text { secções }\end{array}$} & \multirow{2}{*}{$\begin{array}{c}\text { Escolas } \\
\text { técnicas (ou } \\
\text { seç̧ão) e } \\
\text { particulares }\end{array}$} & \multicolumn{3}{|c|}{ Exclusivamente Particulares } & \\
\hline & & & & & & $\begin{array}{l}\text { Até } 30^{\circ} \\
\text { ciclo }\end{array}$ & $\begin{array}{l}\text { Só } 2{ }^{\circ} \\
\text { ciclo }\end{array}$ & $\begin{array}{l}3 .{ }^{\circ} \text { ciclo } \\
2 .{ }^{\circ} \text { ciclo }\end{array}$ & \\
\hline Aveiro & 19 & 3 & & & 5 & 4 & 6 & & 1 \\
\hline Beja & 14 & & & 1 & 2 & & 7 & 1 & 3 \\
\hline Braga & 13 & 4 & & & 1 & & 5 & & 3 \\
\hline Bragança & 12 & 1 & & 1 & 1 & & 8 & & 1 \\
\hline Cast. Branco & 11 & 2 & & & 2 & 2 & 4 & & 1 \\
\hline Coimbra & 17 & 2 & & & 3 & 1 & 6 & & 5 \\
\hline Évora & 14 & 1 & & & 3 & & 5 & & 5 \\
\hline Faro & 16 & 2 & & 1 & 5 & & 2 & & 6 \\
\hline Guarda & 14 & 1 & & & 2 & & 10 & & 1 \\
\hline Leiria & 16 & 1 & & & 5 & 1 & 5 & 1 & 3 \\
\hline Lisboa & 14 & 2 & 3 & 1 & 2 & & 4 & & 2 \\
\hline Portalegre & 15 & 2 & & & 1 & 1 & 5 & & 6 \\
\hline Porto & 17 & 5 & & 1 & 2 & 1 & 7 & & 1 \\
\hline Santarém & 21 & 3 & & & 3 & 2 & 10 & 1 & 2 \\
\hline Setúbal & 13 & 3 & & & 2 & 1 & 2 & & 5 \\
\hline Viana Castelo & 10 & 1 & & & 1 & & 6 & & 2 \\
\hline Vila Real & 14 & 2 & & & 1 & & 6 & & 5 \\
\hline \multirow[t]{2}{*}{ Viseu } & 24 & 2 & & & 1 & 3 & 13 & 1 & 4 \\
\hline & & 37 & 3 & 5 & 42 & $\underline{16}$ & 111 & 4 & \\
\hline Continente & 274 & \multicolumn{5}{|c|}{87} & 131 & & 56 \\
\hline
\end{tabular}

\begin{tabular}{|l|c|c|c|c|c|c|c|c|c|}
\hline Angra do & & & & & & & 1 & & 3 \\
Heroismo & 5 & & & 1 & & & & & 6 \\
Porta & 7 & 1 & & & & 1 & & & 2 \\
Donta & & & & & & & 3 & & 2 \\
Funchal & 7 & 1 & & & & & 2 & \\
\cline { 2 - 8 } & 11 & 1 & & & & & \\
\hline
\end{tabular}




\section{NOTAS}

1 Decreto n. ${ }^{\circ} 20613$, de 5 de Dezembro de 1931, (Diário do Governo, $1 .{ }^{a}$ Série, n. ${ }^{\circ} 285$, de 11 de Dezembro de 1931). Novos estatutos foram publicados em 1932, 1933 e 1934 numa pormenorização crescente do que era e do que podia ser o ensino particular. Ver, igualmente, Decreto n. ${ }^{\circ} 3856$, de 22 de Fevereiro de 1918, art. $6 .^{\circ}$. Com a proclamação da República, em 5 de Outubro de 1910 , triunfaram as ideias positivistas que vibraram um duro golpe na educação tradicional do País — a educação católica —, quer pela expulsão dos Jesuítas e proibição das Ordens Religiosas, quer pela laicização do ensino. No entanto, nalguns aspectos, a reforma cultural da República foi notável, em especial, nos ensinos primário e superior. No que respeita ao ensino secundário particular, o Decreto $n .^{\circ} 3091$, de 17 de Abril de 1917, determina nos seus artigos $385 .^{\circ}$ e $386 .^{\circ}$ : «Todo o indivíduo, corporação ou associação pode, com autorização legal, estabelecer institutos de ensino particular de instrução secundária» e a autorização «deve ser solicitada ao Governo em requerimento apresentado, contra recibo, ao reitor do liceu da área respectiva (art. $381 .^{\circ}$ ), e acompanhado dos seguintes documentos: nome da instituição, planos de estudos que constituem o objecto do ensino e declaração de conformidade do ensino com o plano; cópia do regulamento da instituição; nota do seu regime económico e termo de fiança em que o requerente se obrigue a cumpri-lo; descrição do edifício onde vai funcionar a instituição; de suas condições higiénicas, do número máximo de alunos internos, quando os haja, e de externos que pode admitir; declaração de que o estabelecimento se achará aberto, a toda a hora, sem aviso prévio, às autoridades a quem estiver cometida a inspecção ordinária ou extraordinária do ensino particular. Para os efeitos deste artigo e de todos os mais que dizem respeito à fundação, transferência, encerramento e inspecção de institutos particulares, a área de cada liceu era determinada nos termos do art. 38». Para ficarmos com uma ideia mais clara das limitações à liberdade de ensino e da total dependência em relação ao ensino oficial, dentro dum verdadeiro monopólio de ensino, salientaremos algumas responsabilidades e motivos de encerramento dos estabelecimentos de ensino particular e suspensão dos seus directores: não cumprimento das disposições contidas nos arts. $3 .^{\circ}$ e $4 .^{\circ}$, do Decreto de 8 de Outubro de 1910 e do Decreto de 31 de Dezembro de 1910, relativos ao ensino congregacionista e Constituição da República (1911) e Decreto de 20 de Abril de 1911 referentes à neutralidade do ensino.

2 Considera-se estabelecimento de ensino particular «toda a organização docente instituída por qualquer entidade, que se proponha, com intuitos lucrativos ou sem eles, ministrar o ensino a alunos em comum, desde que se funde para servir o público em geral ou qualquer corporação ou organização particular» (art. $49 .^{\circ}$ ).

3 «É livre e isento de qualquer fiscalização por parte do Estado o exercício de todo o ensino, excepto o que for ministrado a alunos em comum ou tiver por objecto ministrar conhecimentos ou desenvolver aptidões com destino a aquisição de diplomas ou outros instrumentos oficiais comprovativos de habilitações» (art. $1^{\circ} .^{\circ}$. Ver nota 1.

${ }^{4}$ Idem, arts. $2 .^{\circ} \mathrm{e} 9 .^{\circ}$. Ver nota 1 . Embora o diploma proporcionasse a abertura de quaisquer estabelecimentos de educação e ensino, com o fim de ministrar conhecimentos culturais ou desenvolver aptidões para o exercício de profissões, estabelecia-se um controle firme, quer quanto à criação e direç̧ão das escolas, quer quanto à validação oficial das habilitações dos alunos, quer ainda quanto ao pessoal docente ou ao ensino de certas doutrinas - $e$ rigorosamente proibido o ensino de doutrinas contrárias à independência e integridade da Pátria, ao respeito pelas tradições nacionais portuguesas, à segurança do Estado e à moral social.

5 Os estabelecimentos de ensino particular podiam ser:

$1 .^{\circ}$ - De planos e programas de ensino próprios;

$2 .^{\circ}$ - De planos e programas de ensino iguais aos adoptados em estabelecimentos oficiais;

3. - De regime misto, isto é, mantendo cursos segundo os regimes oficiais e outros de programas e planos próprios (art. $64 .^{\circ}$ ). Ver nota 1. 
${ }^{6}$ É permitido o ensino religioso nos estabelecimentos de ensino particular, de harmonia com o que perceitua o artigo $17 .^{\circ}$, do Decreto $n .^{\circ} 11887$, de 15 de Julho de 1926.

$\S$ único - Ainda que ministrado a alunos em comum o ensino religioso não é compreendido na fiscalização por parte do Estado definida por este decreto (art. $4 .^{\circ}$ ). Ver nota 1.

${ }^{7}$ Constituição Política de 1933, art. 44. ${ }^{\circ}$ (Diário do Governo, 1 . $^{a}$ Série, n. ${ }^{\circ} 43$, de 22 de Fevereiro de 1933). Ver Joaquim Ferreira Gomes, «O Direito à Educação nas Constituições Portuguesas», in Novos Estudos de História e de Pedagogia, Coimbra, Liv. Almedina, 1986, p. 97-113.

${ }^{8}$ Idem, art. 14, n. $^{\circ} 4$.

9 Idem, art. 8, n. $^{\circ} 5$.

10 A doutrina da Igreja é a de que o ensino livre representa o reconhecimento de um direito fundamental de educar: da família a quem compete primordialmente o poder de educar, da sociedade civil que deve apoiar a familia, e das demais sociedades em que cabe lugar primacial à Igreja. Variadíssimos documentos pontifícios teorizam este direito dos quais sobressai a Divini Illius Magistri, de Pio XI (1929). Posteriormente, a «Declaração Conciliar sobre a Educação Cristã» - Gravissimum educationis, de Paulo VI (1965) - veio reafirmar este direito no seu $\S 6$ onde se pode ler: é necessário que os pais, cujos primeiros e inalienáveis obrigações e direitos são os de educar os filhos, tenham absoluta liberdade na escolha das escolas. $O$ poder público, a quem pertence proteger e defender as liberdades dos cidadãos, tendo em atenção a justiça distributiva, deve procurar distribuir os subsídios públicos de forma que os pais possam escolher com liberdade absoluta segundo a sua própria consciência, as escolas para os filhos. Do mesmo modo o "Protocolo Adicional de Paris à Convenção Europeia de salvaguarda dos direitos do homem e das liberdades fundamentais» dispõe no seu art. $20^{\circ}:$ A ninguém pode ser recusado o direito à instrução. $O$ Estado, no exercício das funções que assume e no domínio da educação e do ensino, respeitará o direito dos pais de assegurar essa educação e esse ensino de acordo com as suas convicções religiosas e filosóficas.

10 António Leite, «Ensino», in Enciclopédia Luso-Brasileira de Cultura, Verbo, vol. VII, col. 586.

1 Diário do Governo, 1. ${ }^{\mathrm{a}}$ Série, n. ${ }^{\circ} 216$, de 17 de Setembro de 1947.

12 Diário do Governo, 1. ${ }^{a}$ Série, n. ${ }^{\circ} 198$, de 25 de Agosto de 1948.

13 Diário do Governo, 1. ${ }^{\text {a Série, n. }}{ }^{\circ} 138$, de 27 de Junho de 1949.

14 Diário do Governo, 1. ${ }^{\mathrm{a}}$ Série, n. ${ }^{\circ} 197$, de 8 de Setembro de 1949.

15 Diário do Governo, 1. ${ }^{\text {a Série, n. }}{ }^{\circ} 197$, de 8 de Setembro de 1949.

${ }^{16}$ Diário do Governo, 1. ${ }^{a}$ Série, n. ${ }^{\circ}$ 162, de 18 de Julho de 1957.

17 Entre os vários diplomas publicados referentes ao ensino particular devemos ainda mencionar: Decretos $n .^{\circ} 23447$, de 5 de Janeiro de 1934; $n .^{\circ} 29880$, de 4 de Setembro de 1939; n. ${ }^{\circ} 31433$, de 29 de Julho de $1941 ; n .^{\circ} 2241$, de 5 de Setembro de 1942 e Decretos-Lei n. ${ }^{\circ} 34$ 476, de 2 de Janeiro de 1945 e n. ${ }^{\circ} 36405$, de 9 de Julho de 1947, Portaria n. ${ }^{\circ} 17149$, de 4 de Maio de 1959 e Decreto-Lei n. ${ }^{\circ} 44413$, de 23 de Junho de 1962. De entre as Circulares, de maior interesse, da Inspeç̧ão Superior do Ensino Particular, devemos citar: Circular n..$^{\circ} 723$, de 4-11-1942; Circular n. ${ }^{\circ}$ 797-A, de 26-1-1955; Circular n. ${ }^{\circ} 810$, de 19-12-1955; Circular n. ${ }^{\circ} 80$, de 15-10-1955; Circular n. ${ }^{\circ} 832$, de26-9-1957; Circular n. ${ }^{\circ}$ 852, de 10-2-1959; Circular n. ${ }^{\circ} 872$, de 18-8-1960 e Circular n. ${ }^{\circ} 886$, de 12-6-1961.

${ }^{18}$ Constituição Política de 1933, art. 6 (Diârio do Governo, $1 .{ }^{\mathrm{a}}$ Série, ${ }^{\circ}{ }^{\circ} 43$, de 22 de Fevereiro de 1933).

${ }^{19}$ Idem, art. 8..

20 Idem, art. $23 .^{\circ}$.

${ }^{21}$ Idem, art. $14 .^{\circ}$.

22 Idem, art. $42 .^{\circ}$.

23 Idem, art. $44 .^{\circ}$.

$212 \quad{ }^{24}$ Concordata de 7 de Maio de 1940, art. 20. 
25 Decreto-Lei, n. ${ }^{\circ} 37545$, art. 13. n. $^{\circ} 1$ (Diário do Governo, $1^{\text {a }}$ Série, $n .^{\circ} 197$, de 8 de Setembro de 1949).

${ }^{26}$ Idem, art. $13 .^{\circ}, \mathrm{n} .^{\circ} 5$.

$27 \mathrm{O}$ n. ${ }^{\circ}$, do art. $2 .^{\circ}$ afirma: A acção da Inspecção sobre escolas pertencentes a Estados estrangeiros, devidamente autorizados, será limitada ao exame das condições de higiene e salubridade dos edifícios ou instalações e, quando essas escolas ministrarem o ensino a alunos portugueses, à verificação de que não são contrariados os princípios consignados nas Leis do Estado Português nem os interesses nacionais. Sempre, porém, que nessas escolas se ministre cursos regulares dos planos de estudos portugueses, a inspecção far-se-á, quanto a esses cursos, nos termos normais.

28 Idem, art. $12{ }^{\circ}$.

29 Decreto-Lei, n. ${ }^{\circ} 37544$, de 8 de Setembro de 1949 (Diário do Governo, 1. Série, n. ${ }^{\circ} 197$, de 8 de Setembro de 1949).

${ }^{30}$ L'education en devenir. UNESCO, Paris 1975, trad. portuguesa A Educação do Futuro, Lisboa, Liv. Bertrand, p. 289.

${ }^{31}$ Decreto n. $^{\circ} 41192$, de 18 de Julho de 1957, art. 7 (Diário do Governo, 1. ${ }^{a}$ Série, n. ${ }^{\circ} 197$, de 18 de Julho de 1957).

32 Decreto $n .^{\circ} 41192$, de 18 de Julho de 1957 . art. $10, \S 1 .^{\circ}, 2 .^{\circ}, 3{ }^{\circ}$ e $4 .^{\circ}$. Ver nota 32 . Portaria n. 17149 (Diário do Governo, 1.. Série, n. ${ }^{\circ} 101$, de 4 de Maio de 1959).

${ }^{33}$ Decreto n. ${ }^{\circ} 37545$, de 8 de Setembro de 1949 (Diário do Governo, 1. ${ }^{a}$ Série, de 8 de Setembro de 1949).

${ }^{34} \mathrm{O}$ Director dum estabelecimento de ensino particular era a entidade que, munida dum diploma especial passado pela Inspecção Superior do Ensino Particular, dirigia um estabelecimento de ensino particular nos termos do $n .^{\circ} 2$, do art. $7 .^{\circ}$ e do $n . .^{\circ} 1$, do art. $31 .^{\circ}$, do Decreto n. ${ }^{\circ} 37545$. Nos termos do diploma entendia-se por ensino particular todo o que não é ministrado em escolas pertencentes ao Estado (Decreto n. ${ }^{\circ} 37545$, art. $1 .^{\circ}$ ). Em todos os estabelecimentos de ensino particular haverá, pelo menos, um director e quando haja mais que um director, será designado um, com funções de presidente da direcção, e só esse representará o estabelecimento nas relações oficiais com a Inspecção (Decreto n. ${ }^{\circ} 37545, \mathrm{n} .^{\circ} 1 \mathrm{e} 2$, art. $30{ }^{\circ}$ ). Um director não pode ter a seu cargo mais que um estabelecimento e deverá residir numa das suas dependências, sendo internato, e na mesma povoação se for externato (Decreto $n^{\circ} 37545$, art. $31, n{ }^{\circ} 5$ ). As condições exigidas para se poder ser Director dum estabelecimento de ensino particular eram as seguintes: 1) possuir o diploma de professor 2) possuir idoneidade profissional, moral e cívica, de que a Inspecção recolherá rigorosas informações (Decreto n. ${ }^{\circ} 37545$, art. 21 e 29 , n. ${ }^{\circ}$ 2). O requerimento, dirigido ao Ministro da Educação, deveria ser acompanhado dos seguintes documentos: certificado de registo criminal e declaração nos termos do Decreto-Lei n. ${ }^{\circ} 27003$, de 14 de Setembro de 1936. A título provisório podia ser autorizado, sob proposta dos proprietários do estabelecimento, que um professor, depois de ter requerido o diploma de director e enquanto não fosse passado, pudesse dirigir esse estabelecimento. As disposições legais determinavam que nenhum estabelecimento de ensino particular pudesse ser dirigido por um professor cujo diploma mencionasse cursos de categoria inferior a alguns dos que alí eram professados (Decreto $\mathrm{n} .^{\circ} 37545$, art $31, \mathrm{n} .^{\circ}$ ).

${ }^{35}$ O ensino particular é considerado função pública, para o efeito das responsabilidades a exigir àqueles que o exercem (Lei $\mathrm{n} .{ }^{\circ} 2033$, Base $\mathrm{I}, \mathrm{n} .{ }^{\circ} 2$ ). $O$ exercício das funções de director de estabelecimento de ensino particular fica sujeito, na parte aplicável, aos preceitos relativos aos reitores, directores dos estabelecimentos similares do ensino oficial (Decreto $\mathrm{n} .{ }^{\circ} 37545$, art. $31, \mathrm{n} .^{\circ} 7$ ). Tanto os professores como os directores podiam ser disciplinarmente punidos quando cometessem infracções, faltando ao cumprimento dos deveres que lhes incumbem, desrespeitando as leis ou os princípios pedagógicos ou não tendo, dentro ou fora da escola, procedimento moral irrepreensível (Decreto n. ${ }^{\circ} 37545$, art. 32, n. ${ }^{\circ}$ ). Observar-se-ão em tudo o mais as disposições que puderem ser aplicadas do Estatuto Disciplinar dos Funcionários Civis (Decreto n. ${ }^{\circ} 37545$, art. $32 .^{\circ},{ }^{\circ}{ }^{\circ}$ ). 
36 Boletim, CODEPA, n. ${ }^{\circ} 13$, Lisboa, 1965, p. 22.

37 Actas da Câmara Cooperativa, n. ${ }^{\circ}$ 56, IX Legislatura, 30 de Junho de 1967.

${ }^{38}$ Inocêncio Galvão Teles, Para um Estatuto da Educação Nacional, Lisboa, 1966, p. 39.

${ }^{39}$ Idem, ob. cit., p. $39-40$.

40 Idem, ob. cit., p. 40.

41 Inocêncio Galvão Teles, Projecto do Estatuto da Educação Nacional, Lisboa, 1969, art. $4 .^{\circ}$.

${ }^{42}$ Idem, art. $5 .^{\circ}$.

43 Idem, art. $110^{\circ}$.

44 Idem, art. $7 .^{\circ}$.

45 Idem, art. 19..$^{\circ}$

46 Idem, art. $46 .^{\circ}$.

${ }^{47}$ Idem, art. $690^{\circ} \mathrm{e} 70{ }^{\circ}$.

48 Idem, art. $900^{\circ}$.

49 Idem, art. 10, n. $^{\circ} 3$ e $91 .^{\circ}$.

${ }^{50}$ Idem, art. $95 .^{\circ}$.

51 Idem, art. $94 .^{\circ}$.

52 Idem, art. 97..

${ }^{53}$ Idem, art. $98 .^{\circ}$.

${ }^{54}$ Idem, art. 99..

55 Idem, art. 100..$^{\circ}$ Já, em 1967, nos Trabalhos Preparatórios do Estatuto da Educação Nacional se afirmava que os colégios não eram um negócio e que a sua rentabilidade era mínima quando não mesmo deficitária. É em função desta situação que o M.E.N., em 1971, inicia a atribuição de subsídios a estabelecimentos de ensino particular. Mais tarde (1973), o M.E.N. passa a conceder subsídios regulares com exigência de frequência gratuita, nessas escolas, situadas em locais em que não havia ensino público. Eram as escolas supletivas de ensino público.

${ }^{56}$ Idem, art. 189, n. $^{\circ} 3$. Ver, igualmente, arts. 210 a 215.

57 Idem, art. $81 .^{\circ}, \mathrm{n} .{ }^{\circ} 3$.

${ }^{58}$ Idem, art. $87, \mathrm{n} .^{\circ} 3$.

59 Idem, art. 88..

${ }^{60}$ Nota Oficiosa, de 27 de Setembro de 1972 (Boletim Oficial, Supl., MEN, Lisboa, Outubro, 1972).

${ }^{61}$ Decreto-Lei n. ${ }^{\circ} 254 / 72$, de 27 de Julho.

62 Os valores apresentados foram obtidos no Anuário Estatístico (de1949 a 1960), INE, Lisboa, na Estatística da Educą̧ão (1949-50, 1950-51,1952-53, 1953-54, 1954-55, 1956-57,1958-59), INE, Lisboa e na Evolução do Sistema de Ensino (1960-61 a 1973-74), MEIC, Lisboa. Estes valores diferem, no entanto, dos recolhidos nos serviços da Direç̧ão Geral do Ensino Secundário e da Inspecção Geral de Ensino. (ver Anexo - Quadro I). No ensino liceal, até ao ano lectivo de 1967-68, os valores apresentados representam a soma das frequências dos sete anos de duração deste ramo de ensino. Nos anos lectivos de 1968-69 e 1969-70 entraram em funcionamento, pela primeira vez, respectivamente o $1 .^{\circ} \mathrm{e} o 2 .^{\circ}$ anos de ciclo preparatório do ensino secundário, integrados na Direcção Geral de Ensino Básico. As frequências globais do ensino liceal, em 1968-69 e 1969-70, referem-se a 6 e 5 anos de escolaridade. No ano lectivo de 1972-73 iniciou-se o ensino liceal nocturno e as frequências registadas incluem também este regime de ensino. No ensino técnico, os números globais registados incluem o ensino diurno e o ensino nocturno. Incluíram-se, igualmente, as frequências dos dois anos do ciclo preparatório do ensino técnico, durante os anos lectivos em que funcionou. Este ciclo assim como o $1 .^{\circ}$ ciclo do ensino liceal foi substituído pelo ciclo preparatório do ensino secundário. Em 1971 as Direcçб̃es Gerais do Ensino Liceal e do Ensino Técnico-Profissional fundiram-se na Direcção Geral do Ensino Secundário, embora permanecendo distintos os dois ramos de ensino liceal e técnico, até ao ano lectivo de 1974-75. 
63 António Manuel P. Matoso Martinho, A Escola Avelar Brotero - 1884-1974. Contributo para a história do ensino técnico-profissional, Guarda, 1993.

${ }^{64}$ A forte expansão do ensino oficial pode explicar-se pelos seguintes motivos: alargamento da escolaridade obrigatória, criação do curso unificado da Telescola, criação do ciclo preparatório do ensino secundário, estudos visando a reestruturação do ensino técnico e criação do curso geral unificado experimental.

${ }^{65}$ Ciclo Preparatório do Ensino Secundário, Ed. da Direcção Geral do Ensino Primário, Lisboa, 1960, p.167-168.

${ }^{66}$ No distrito de Viseu (com 24 concelhos interiores), 4 não tinham qualquer estabelecimento de ensino secundário, 17 só tinham estabelecimentos de ensino particular e 3 tinham estabelecimentos de ensino público e particular.

\section{BIBLIOGRAFIA}

Anuário Esatatístico: 1949, 1950, 1951, 1952, 1953, 1954, 1955, 1956, 1957, 1958, 1959, 1960 , INE, Lisboa.

Assembleia Nacional: «Discussão da Proposta de lei da reforma do ensino técnico-profissional», in Diário das Sessões, IV Legislatura, 1946, 1947, n. $.^{\text {os }} 61,74$ a 86 e Supl. ao n. ${ }^{\circ} 112$.

Câmara Corporativa, «Parecer $n .^{\circ} 13$ sobre a Proposta de Lei, $n .{ }^{\circ} 99$. Reforma do ensino técnico-profissional», in Actas da Câmara Corporativa, IV Legislatura, 1946.

«Projecto de Proposta de Lei, n. ${ }^{\circ}$ 4/IX - III Plano de Fomento para 1963-73», in Actas da Câmara Corporativa, IX Legislatura, 1967, n. ${ }^{\circ} 55$.

«Parecer subsidiário da subsecção da seç̧ão de interesses de ordem cultural sobre o capítulo $\mathrm{X}$, do III Plano de Fomento, Educação e Investimento», in Actas da Câmara Corporativa, IX Legislatura, $n .^{\circ} 77$.

CARRASCO, Garcia, 1969, La politica docente. Estudio a la luz del Vaticano II, BAC, Madrid, 1969.

CRUZ, J. Braga da, 1953, Direitos da Família, da Igreja e do Estado, Lisboa, s/d.

CRUZ, J. Braga da, «Direitos e deveres do Estado na educação», in Semanas sociais portuguesas, Braga.

CRUZ, J. Braga da, O problema da educação, Lisboa, s/d.

Educação do Futuro (A), 1978,UNESCO, Lisboa, Liv. Bertrand.

Estatística de Educação, 1949-50, 1950-51, 1951-52, 1952-53, 1953-54, 1954-55, 1956-57, 1958-59, INE, Lisboa.

FERNANDES, Rogério, 1973, Situação da Educação em Portugal, Lisboa, Moraes Editores. FERNANDES, Rogério, 1967, Ensino: Sector em crise?, Lisboa, Prelo.

FRANCO, António L. Sousa, 1971. «O ensino livre na Reforma», in Rev. Brotéria, vol. 92, n. ${ }^{\circ}$, Lisboa.

GOMES, Joaquim Ferreira, 1964, «Da Directoria-Geral dos Estudos ao Ministério da Educação», in Revista Portuguesa de Pedagogia, XVIII, Coimbra.

GOMES, Joaquim Ferreira, 1984, «O direito à educação nas Constituições Portuguesas», in Revista Portuguesa de Pedagogia, XVIII, Coimbra.

GOMES, Joaquim Ferreira, 1985, «A introdução e o prolongamento da obrigatoriedade escolar em Portugal», in Revista Portuguesa de Pedagogia, XIX, Coimbra.

GOMES, Joaquim Ferreira, 1984, Estudos de História e de Pedagogia, Coimbra, Liv. Almedina.

GOMES, Joaquim Ferreira, 1986, Novos estudos de História e de Pedagogia, Coimbra, Liv. Almedina.

MARTINHO, António Manuel P. Matoso, 1993, A Escola Avelar Brotero - 1884-1974. Contributo para a história do ensino técnico-profissional, Guarda. 
MARTINS, C. Alves et al., 1963, Análise quantitativa da estrutura escolar portuguesa, 1950-1959, Lisboa, Centro de Estudos de Estatística Económica.

Nova História de Portugal, 1992, vol. XII, - Portugal e o Estado Novo (1930-1960), Lisboa, Editorial Presença.

PINTO, F. Leite, 1957, Discursos, Lisboa.

PINTO, F. Leite, 1969, A educação no espaço português, Lisboa.

Reforma do Sistema Educativo (A), 1973, Lisboa, MEN.

SAMPAIO, José Salvado, 1973, Evolução do Ensino em Portugal - 1940/41-1966/67. Contribuição monográfica, Lisboa, Fund. C. Gulbenkian.

SAMPAIO, José Salvado, 1980, Portugal - A educação em números, Lisboa, Livros Horizonte.

SIMÃO, Veiga, 1970, Batalha da Educação, Lisboa, MEN.

SIMÃO, 1981, $O$ direito à educação, Lisboa, MEN.

SIMÃO, 1972, Uma decisão histórica, Lisboa, MEN.

Sistema de Ensino em Portugal, 1981, Fund. C. Gulbenkian, Lisboa.

TELES, Inocêncio Galvão, 1969, Temas de Educação, Lisboa, MEN, 1966.

TELES, Inocêncio Galvão, Estatuto da Educação Nacional - Projecto, Lisboa, MEN.

Trabalhos preparatórios do Estatuto da Educação Nacional, vol. II, Ensino Particular, Lisboa, 1967. 


\section{ANEXO \\ FREQUÊNCIA DO ENSINO SECUNDÁRIO}

(1950-51 a 1973-74)

\begin{tabular}{|c|r|r|c|c|c|c|}
\hline \multirow{2}{*}{$\begin{array}{c}\text { Ano } \\
\text { Lectivo }\end{array}$} & \multicolumn{3}{|c|}{ Ensino Liceal } & \multicolumn{3}{c|}{ Ensino Técnico-Profissional } \\
\cline { 2 - 7 } & \multicolumn{1}{|c|}{ Total } & Oficial & Partic. & \multicolumn{1}{c|}{ Total } & Oficial & Partic. \\
\hline $1950-51$ & 48485 & 21962 & 26523 & 34216 & 30078 & 4238 \\
$1951-52$ & 51577 & 23677 & 27900 & 34676 & 30160 & 4516 \\
$1952-53$ & 54370 & 24909 & 29461 & 35170 & 30878 & 4292 \\
$1953-54$ & 58721 & 26645 & 32076 & 38255 & 34084 & 4171 \\
$1954-55$ & 62680 & 27930 & 34750 & 41648 & 37903 & 3745 \\
$1955-56$ & 68873 & 30951 & 37922 & 47825 & 43630 & 4145 \\
$1956-57$ & 76637 & 31896 & 44741 & 53968 & 49376 & 4592 \\
$1957-58$ & 82962 & 34812 & 48150 & 60745 & & \\
$1958-59$ & 91020 & 37859 & 53161 & 71575 & 66689 & 4886 \\
$1959-60$ & 101969 & 42049 & 59920 & 83507 & 77716 & 5791 \\
$1960-61$ & 11821 & 46060 & 65761 & 97462 & 92000 & 5462 \\
$1961-62$ & 118250 & 49274 & 68976 & 110535 & 104579 & 5956 \\
$1962-63$ & 129439 & 53932 & 75507 & 123327 & 116715 & 6612 \\
$1963-64$ & 139143 & 57889 & 81254 & 132755 & 125620 & 7135 \\
$1964-65$ & 144657 & 59780 & 84877 & 144719 & 136654 & 8065 \\
$1965-66$ & 149733 & 62036 & 87697 & 154074 & 144992 & 9082 \\
$1966-67$ & 155445 & 66391 & 89054 & 155512 & 146323 & 9189 \\
$1967-68$ & 160302 & 69642 & 90660 & 156395 & 146586 & 9808 \\
$1968-69$ & 143970 & 59030 & 84940 & 137260 & 128063 & 9197 \\
$1969-70$ & 120373 & 53913 & 66460 & 120979 & 114134 & 6845 \\
$1970-71$ & 137259 & 65226 & 72033 & 127027 & 119899 & 7128 \\
$1971-72$ & 155672 & 79030 & 76642 & 130714 & 123060 & 7654 \\
$1972-73$ & 178547 & 99506 & 79041 & 140195 & 132123 & 8072 \\
$1973-74$ & 159328 & 126592 & 32736 & 136485 & 134874 & 1611 \\
\hline
\end{tabular}

\begin{tabular}{|r|r|r|}
\hline Ens. Lic. & Ens. Téc. & Total \\
\hline & & \\
& & \\
& & \\
& & \\
& & \\
39924 & 41759 & 71683 \\
3623 & 45307 & 78930 \\
36173 & 54998 & 91171 \\
40142 & 66027 & 106169 \\
42659 & 77279 & 119938 \\
46302 & 89821 & 136123 \\
50191 & 102894 & 153085 \\
54567 & 116332 & 170899 \\
58815 & 122759 & 181569 \\
62656 & 133598 & 196254 \\
66018 & 142565 & 208583 \\
68743 & 144476 & 213219 \\
67535 & 144388 & 211923 \\
60471 & 130665 & 191136 \\
55492 & 114134 & 169626 \\
69254 & 118256 & 187610 \\
84760 & 122967 & 207727 \\
104477 & 127289 & 231766 \\
127023 & 134993 & 262016 \\
\hline
\end{tabular}

Fonte: Estatística da Educação, INE, Lisboa Anuário Estatístico, INE, Lisboa

Fonte: DGES e IGE 